\title{
John Edmund Hodgson \\ Honorary Fellow
}

$1875-1952$

\begin{abstract}
THE NAME OF J. E. HODGSON has been familiar to members of the Royal Aeronautical Society for over a quarter of a century, as the Honorary Librarian. He was appointed Honorary Librarian at a Council Meeting held on 23rd October 1923 , at which the author of the memoir was present, then, as a Member of Council. In the fruitful years he served the Society so well and so disinterestedly, the advice and practical help he so readily gave, have made the Library of the Society one of the most renowned in the world.
\end{abstract}

Although in the last twelve months he had been failing in health and had been prevented from attending those functions of the Society which in the past he had so seldom missed, he did not overlook anything which might add to the glory of the Society's library. Only six weeks before his death on 10th April 1952 (the day before his 77th birthday) he informed the Secretary that a copy, published in 1684, of that rare work Bishop Wilkins' $A$ Discovery of a New World (with a chapter on Flying to the Moon) would be coming up for sale and advising it should be bought. It is now in the Society's library.

On 12th January 1926 the Society celebrated the 60th Anniversary of its foundation, by a Conversazione in the Science Museum, South Kensington. During that evening Hodgson, in an address to members of the Society and many distinguished guests, finished on a note which showed his clarity of vision in air matters. "If by the exercise of their influence, as individual members not less than as an organised body, they helped to make it more clearly realised that this country, while remaining faithful to its great tradition as a seafaring race, must develop an ' air sense' and become an air-faring people, then the Society would have added to its many great services to the Science of Aeronautics, no less great a service to the nation and to the Empire."

Only two years previously the Oxford University Press had published his monumental History of Aeronautics in Great Britain, a work which became a classic in his own life time. Its scholarship and research showed the quality of the man. Hodgson was learned in literature, a lover of fine books, fine printing and fine bindings, and he spoke and wrote with authority, for he had that high integrity which prevented him from an expression of opinion without the knowledge research gave to him. It is noteworthy that he was on the Councils of the Newcomen Society and the English Association for many years and his loss will be felt deeply in many quarters.

The year 1928 was the centenary of the death of James Sadler, the first English aeronaut. It was Hodgson who, that year, rescued Sadler's name from comparative obscurity and persuaded many of his friends, as Honorary Librarian of the Society, to subscribe to a memorial tablet to Sadler in St. Peter's Church, Oxford, in which city Sadler was born. Hodgson's lecture on 21st March 1928 on James Sadler, Aeronaut, Chemist, Engineer and Inventor, was not only a tribute to Sadler but an unconscious one to the lecturer himself.

Those who visited the International Aero Exhibition at Olympia in July 1929 will remember the remarkable exhibit of historical books, engravings, MSS., and other aeronautical items, prepared and arranged by Hodgson on behalf of the Society. He not only wrote most of the descriptions, but provided the greater part 
of the old aeronautical prints and rare books which were shown. Many of them were afterwards exhibited in Berlin.

During the 1914-18 War Hodgson bought the astonishing collection of John Cuthbert, dating from 1820 , of old balloon prints and posters, to which he added considerably. Though tempted by high offers from America he accepted an offer in 1947 from Sir Frederick Handley Page when he learnt that it was the intention of Sir Frederick to present the collection to the Society, where Hodgson had always hoped it might find a permanent home. The collection is now one of the Society's prized possessions.

In 1933 there was published by the Newcomen Society, the Note Book of Sir George Cayley, with an introduction by Hodgson. On 6th January 1936 he lectured before the Royal Aeronautical Society on "The Founder of British Aeronautical Science."

In that lecture on Cayley he said, "I fully realise that to those working in the full flood of present day problems and practice, matters historical are apt to be disregarded as of no practical interest or value. That, I would venture to suggest, is not a wise view-on the contrary we cannot afford to ignore the lessons that history and experience of the past teach. Moreover, to disregard them is to lose the inspiration and encouragement which come from knowledge, however slight, of the problems and difficulties which beset the great pioneers of the past, and the manner in which they overcame them."

It is fitting in this age of an "I couldn't care less" attitude among so many, that Hodgson's words should be recalled and recorded afresh.

The year 1943 was the centenary of W. S. Henson and in the April JournaL of the Society of that year Hodgson contributed a paper on the "Aerial Steam Carriage" of 1843.

During the last twelve months of his life Hodgson was working on a life of Sir George Cayley as well as working on a catalogue of some Johnsoniana. At Scarborough, in 1951, much of the success of the Exhibition held there in memory of Cayley, was due to Hodgson's help and advice.

Hodgson's reputation is high and safe in many directions. He had those virtues which are becoming rarer as civilization becomes more common, loyalty, idealism, humility and utter integrity of mind and action. He attracted friends from the highest to the lowest, for he could "walk with kings and keep the common touch." His very qualities misled many as to the inner greatness of the man. With them all he was passionately fond of good music, and had a knowledge of boxing and athletics generally which would have enabled him to hold his own in sporting company. $\mathrm{He}$ was, too, an ardent cricket and rugger enthusiast.

Hodgson was proud of being a President of the Johnson Club and for long was its Honorary Treasurer. He became a trustee, at the suggestion of Lord Harmsworth, of Johnson's House in Gough Square, an honour which gave him great personal satisfaction as a learned Johnsonian.

In the London Mercury for May 1924 he wrote a paper entitled "Johnson on Ballooning and Flight."

Earlier in this memoir it was said that Hodgson was learned in literature. One may fittingly conclude, therefore, with two quotations, one of which he used himself in his talk before the Society in 1926. It is from the Johnson he loved so well. "I will be conquered. I will not capitulate," and the other is from Edmund Burke, written towards the end of the 18th century,

"These gentle historians dip their pens in nothing but the milk of human kindness."

That was John Hodgson, Honorary Fellow of this Society. 
Lieut.-Col. W. Lockwood MARSH writes:-

I should like to pay a personal tribute to John Hodgson in the JourNaL, since I was instrumental in his becoming Honorary Librarian of the Society.

I first met him in 1918 through Air Commodore Maitland with whom I shared a passion for old books on aeronautics, a subject on which Hodgson was of course, by profession, an expert. Thereafter we met frequently and during the preparation of his History of Aeronautics in Great Britain we were in constant touch. Indeed, he honoured me by allowing me to read much of it before publication both in manuscript and proof.

Particularly impressive, 1 think, was the soundness of his judgment in appraising the work of the various early experimenters despite at the outset his complete lack of any technical knowledge of aeronautics whatever. The appearance of his book was a major event in aeronautics, and indeed in literature, since it set a standard and provided a classic example of what a work of that nature should be; not least in the truly magnificent index, to the form of which he gave much thought.

I shall never forget his delight and modest pride when he became the owner of the famous Cuthbert collection, the almost legendary assembly of prints whose continued existence was for long uncertain and its whereabouts unknown. He devoted much anxious consideration to the problem of its future home and was greatly relieved when, owing to the modest value he was willing to put on it, it came to rest with the Society where it is to be hoped it will remain in perpetuity.

My most treasured memory of him is of our spending a week together in Paris, whither with characteristic generosity he accompanied me to help in the selection of prints for reproduction in my own Aeronautical Prints and Drawings. During this week we agreed which prints we should each reproduce in our respective books so as to avoid needless repetition. In the course of it we visited under the expert guidance of Mr. Charles Dollfus every known collection of prints and drawings and paid a pious pilgrimage to the sites of the early balloon ascents. With such a companion all this was a quite unforgettable experience.

John Hodgson was in the widest sense a truly good man. He possessed a simplicity and pureness of spirit which will keep his memory for ever green in the minds of all who knew him. It was this quality which made him, as he was, so beloved of children. He was indeed a most lovable man. 